\title{
Ambidexterity strategies in illegitimate institutional contexts: the role of informal institutions
}

Ambidexterity strategies

\section{Estrategias de ambidexteridad en contextos institucionales ilegítimos: el papel de las instituciones informales}

Jacobo Ramirez

Department of Management, Society and Communication (MSC), Copenhagen Business School (CBS), Frederiksberg, Denmark

Claudia Vélez-Zapata

Escuela Economía, Administración y Negocios, Universidad Pontificia Bolivariana, Medellin, Colombia, and

Sergio Madero

Tecnologico de Monterrey, Campus Monterrey, Monterrey, Mexico
(C) Jacobo Ramirez, Claudia Vélez-Zapata and Sergio Madero. Published by Emerald Publishing Limited. This article is published under the Creative Commons Attribution (CC BY 4.0) licence. Anyone may reproduce, distribute, translate and create derivative works of this article (for both commercial and non-commercial purposes), subject to full attribution to the original publication and authors. The full terms of this licence may be seen at http://creativecommons.org/licences/by/4.0/ legalcode

This paper was the winner of the best paper award in the recent Iberoamerican Academy of Management conference (Management Research Editor's Best Paper Award in the Xth International Conference of the Iberoamerican Academy of Management, held in New Orleans in December, 2017) This research was supported by a grant from MSC HoDD.
Received 14 February 2018 Revised 13 March 2018 28 March 2018 Accepted 28 March 2018 


\section{MRJIAM 16,2}

\begin{abstract}
Purpose - The purpose of this paper is to analyze firms and employees' strategies in illegitimate institutional contexts in which non-governmental armed groups enforce illegitimate activities in firms and civil society. The aim is to recognize employees as key and effective players in implementing ambidextrous organizational and human resource management (HRM) strategies. We know little regarding employee norms and behaviors in complying with global market standards while surviving in environments characterized by high levels of civil violence and crime.

Design/methodology/approach - This paper presents an explorative, qualitative study based on 65 semi-structured interviews and conversations with employees in Colombia and Mexico over four years.

Findings - The findings of this paper indicate that the presence of non-governmental armed groups forces firms, HR departments and front-line managers to strategically exploit security measures inspired by employees' informal institutions to protect firm assets while implementing innovative exploration strategies to improve employee work conditions, survive in unsafe environments and remain internationally competitive.

Originality/value - The findings suggest that organization, HRM and employee ambidexterity are organizational advantages in illegitimate institutional contexts. This study contributes to the literature linking ambidexterity and institutional theory by emphasizing informal institutions when examining employment relationships in unsafe environments.
\end{abstract}

Keywords Mexico, Colombia, Ambidexterity, Informal institutions, Illegitimate institutions, Non-governmental armed groups

Paper type Research paper

\title{
Resumen
}

Objetivo - o objetivo deste trabalho é fazer uma análise das estratégias de empresas e empregados em contextos institucionais ilegítimos onde grupos armados afetam empresas e sociedade civil através da implementação de atividades fora da lei. O objetivo é reconhecer aos empregados como funcionários-chave e efetivos na implementação de estratégias de ambidestria organizacional e da gestão de recursos humanos (HRM). Conhecemos poucas informações sobre as políticas, estratégias, práticas e comportamentos dos funcionários para cumprir com os padrões globais, as suas responsabilidades e funções no cargo, enquanto procuram sobreviver em simultâneo em contextos que têm um alto nível de violência e criminalidade contra a população.

Design/metodologia/abordagem - Este artigo apresenta um estudo exploratório sob uma abordagem qualitativa com base em 65 entrevistas semiestruturadas e conversas com funcionários na Colômbia e no México ao longo de um período de quatro anos.

Conclusões - Nossas descobertas indicam que os grupos armados não governamentais têm forçado organizações, setores de recursos humanos e gerentes da linha de frente a explorar estrategicamente medidas de segurança inspiradas nas instituições informais para proteger os ativos da empresa. Além disso, as empresas têm adotado estratégias exploratórias inovadoras para melhorar as condições de trabalho dos funcionários, lidar e sobreviver em ambientes de risco e continuar sendo competitivas internacionalmente.

Originalidade/valor - Nossas descobertas sugerem que a organização, a gestão dos recursos humanos e ambidestria dos funcionários são uma vantagem organizacional em contextos institucionais ilegitimos. Nosso estudo tem como objetivo contribuir para a literatura que liga a ambidestria com a teoria institucional com o fim de destacar o papel das instituições informais na análise das relações de trabalho em ambientes inseguros.

Palabras chave - Instituições Informais, instituições ilegítimas, Ambidestria, Gupos armados nãogovernamentais, Colômbia, México

Tipo de artículo - Trabajo de pesquisa

\section{Resumo}

Propósito - el propósito de este trabajo es analizar las estrategias de las empresas y los empleados en contextos institucionales ilegítimos en los que los grupos armados afectan a las empresas y la sociedad civil mediante la implementación de actividades al margen de la ley. El objetivo es reconocer a los empleados como actores clave y efectivos en la implementación de estrategias de ambidestreza organizacional y de gestión de recursos humanos (HRM). Sabemos poco sobre las políticas, estrategias, prácticas y comportamientos de los empleados para cumplir con los estándares mundiales, sus responsabilidades y funciones en el cargo y al 
mismo tiempo sobrevivir en entornos caracterizados por un alto grado de delincuencia y violencia hacia la población civil.

Diseño/metodología/enfoque - este documento presenta un estudio exploratorio bajo una perspectiva cualitativo basado en 65 entrevistas semiestructuradas y conversacionales con empleados en Colombia y México durante un período de cuatro años.

Hallazgos - nuestros hallazgos indican que grupos armados al margen de la ley han obligado a organizaciones, departamentos de recursos humanos y gerentes de primera línea a explotar estratégicamente medidas de seguridad inspiradas en instituciones informales para proteger activos de la empresa mientras implementan estrategias exploratorias innovadoras para mejorar las condiciones de trabajo de los empleados, sobrellevar y sobrevivir en entornos de riesgo e inseguros y, a la par, seguir siendo competitivos en el plano internacional.

Originalidad/valor - nuestros hallazgos sugieren que la organización, la gestión de recursos humanos y la ambidestreza de los empleados son una ventaja organizativa en contextos institucionales ilegítimos. Nuestro estudio tiene como objetivo contribuir a la literatura que vincula la ambidestreza y la teoría institucional destacando las instituciones informales para examinar las relaciones en entornos inseguros.

Palabras clave - Instituciones informales, Instituciones ilegítimas, Ambidestreza, Grupos armados no gubernamentales, Colombia, México

Tipo de artigo - Trabalho de investigação

\section{Introduction}

Armed conflict around the world accounted for more than 80 per cent of fatalities worldwide in, 2017, impacting civilians in cities and towns (IISS, 2017), as well as firms' investments (Ganson and Wennmann, 2016). We know little about the ability of civilians to resist and recover from armed conflict or terrorist attacks (Dau et al., 2018), despite the fact that this knowledge could be a competitive advantage to firms operating in high-security risk institutional contexts. Management research has long studied firms' challenges by examining formal institutions, laws and regulations (North, 1990), including those of corrupt governments, inefficient regional economic development projects and the fall-out from neoliberal development policies (Martínez Rangel and Reyes Garmendia, 2012). Other scholars have adopted the informal institutions approach (traditions, customs, norms and culture) - also referred to as the cultural-cognitive pillar (DiMaggio and Powell, 1983; Scott, 2014) -to discuss management policies and practices in the corresponding institutional context (Paauwe and Boselie, 2003) and to propose the professionalization of management practices, known as normative mechanisms (Scott, 2014). However, institutional theory researchers (e.g. Marquis and Raynard, 2015; North, 1990; Oliver, 1991; Scott, 2014; Rao and Greve, 2018) have tended to overlook the impact of high-security risks on management studies, despite these risks reflecting a key aspect of the institutional environment (Bader et al., 2015; Hiatt and Sine, 2014).

In this paper, we propose the use of illegitimate institutions to study firms in the armedconflict context. We understand the illegitimate institutional context to be based on formal institutions that are:

- unable to provide basic human rights to civil society, such as physical security;

- characterized by fraudulent and dishonest environments when enforcing laws and regulations; and

- lacking the prevention and ability to fight enforcement of illegal norms and attacks (e.g. extortion, physical violence) on civil society and firms by non-governmental armed groups (Rosen et al., 2016; Transparency International, 2018; Parlevliet, 2007; Sutter et al., 2013; Woody, 2017).

\section{Ambidexterity strategies}


MRJIAM

16,2

The need to ensure employee survival in the presence of threats and criminal acts by nongovernmental armed groups (for example, in a narcoterrorism context) (Campbell and Hansen, 2014) drives firms to exploit existing strategies and to explore new strategies, referred to as ambidexterity - the ability "to use both hands alike" (OED, 2016). Scholars have used the ambidexterity concept to discuss integrative management models (Caniëls and Veld, 2016; Duncan, 1976; Havermans et al., 2015; Patel et al., 2013; Raisch and Birkinshaw, 2008). However, ambidexterity management studies are limited by a lack of consideration for how the causal impacts of the illegitimate institutional context shape employees' and firms' responses to it. In this study, we investigate how ambidexterity theory can illuminate management and organizational decisions in illegitimate institutional contexts.

We selected private firms in Colombia and Mexico to develop our research for two reasons:

(1) Colombia and Mexico are classified as high security risk countries (IISS, 2017) because of armed conflict with non-governmental armed groups, such as drug cartels.

(2) The implementation of neoliberal reforms (Williamson, 2008) has resulted in positive performance in terms of attracting foreign direct investment (FDI) and exports (Corficolombiana, 2018; Secretaría de Economía, 2017).

These features imply that employees and firms are implementing strategies to cope with illegitimate institutions while meeting local and international market demands.

Our research question was as follows:

RQ1. How do firms integrate informal institutions as part of their strategy to meet market demand while coping with the consequences of illegitimate institutional contexts?

We developed an explorative qualitative study based on 65 semi-structured interviews and conversations with employees in Colombia and Mexico between 2014 and 2018. Our results illustrate how senior managers exploit the "traditional," taken-for-granted informal norms and behaviors developed by civil society, to survive in an illegitimate institutional context. These informal norms and behaviors appear to be absorbed by firms, and developed as part of their policy, as a security measure to protect both employees and the firms' infrastructure. Our findings seem to be aligned with employees' abilities, suggesting that it is not sufficient for managers and subordinates in an illegitimate institutional context to be competent at their jobs; they must also be savvy in the local context to strategically design and implement exploitative-explorative (March, 1991) policies and practices. We posit that in the illegitimate institutional context, civil society might seek mutual support based on preexisting institutional legacies (Rao and Greve, 2018) to resist and recover from, for example, armed conflict or narcoterrorism attacks (Rahman and Vuković, 2018), by relying on norms and behaviors received through their networks rather than seeking protection from formal institutions.

This study contributes to the institutional managerial tradition (Cantwell et al., 2010) by investigating how illegitimate institutional contexts shape informal institutions at the organizational and human resource management (HRM) levels, as well as the role that employees play in exploiting and exploring day-to-day policies and practices, suggesting the need to re-study (e.g. Alcadipani and Rosa, 2011) ambidexterity in similar contexts. These concerns could serve as a learning platform for firms that investment in contexts marked by corruption (Transparency 
International, 2018), autocracy, or dictatorship (The Economist, 2018; PlanetRulers, 2018), enabling managers to devise ambidextrous (March, 1991) strategies for timely responses to threats such as terrorist attacks (e.g. Colville et al., 2013).

The remainder of this paper is organized as follows. First, we present our theoretical background, followed by our methodology and findings. Then, a general discussion and the implications of the findings are presented, to develop the ambidexterity research in relation to changing behaviors at the organizational, HRM and employee levels in dynamic institutional contexts.

\section{Theoretical background}

Institutions are the "rules of the game in a society" (North, 1990, p. 3). Traditionally, institutional research has emphasized written, formal (laws, policies and regulations) and unwritten, informal (traditions, customs, norms and culture) institutions (North, 1990) that shape strategic organizational decisions to design and implement policies and practices, such as those for HRM (e.g. Davila and Elvira, 2015; Paauwe and Boselie, 2003). Scott (2014) proposed institutional, normative and cultural-cognitive pillars, also referred to as coercive, normative and mimetic mechanisms (DiMaggio and Powell, 1983), respectively, to study firms and individuals executing their power using a variety of instruments.

Regulatory mechanisms allow firms to establish rules, inspect others' conformity to these rules and when necessary, manipulate sanctions, rewards or punishments in attempts to influence future behavior (Scott, 2014). These tactics are coercive (DiMaggio and Powell, 1983) actions, policies, rules and laws (North, 1990). Normative mechanisms stem primarily from professionalization (DiMaggio and Powell, 1983). They reflect values, beliefs, norms and assumptions (Scott, 2014), and they introduce a prescriptive, evaluative and obligatory dimension into social life (Scott, 2014). Codes of conduct, norms, standards or quality certifications form part of a firm's normative mechanisms (Paauwe and Boselie, 2003). The cultural-cognitive pillar stresses the centrality of the cultural-cognitive elements of institutions or informal institutions (North, 1990), which are often less strictly enforced. The culturalcognitive pillar encompasses the shared conceptions that constitute the nature of social reality and create the frames through which meaning is created (Scott, 2014). Practices and customs may be difficult to understand and assimilate; for example, employees might choose to mimic others' behaviors when responding to uncertainty (DiMaggio and Powell, 1983; Davila and Elvira, 2012; Paauwe and Boselie, 2003).

Institutional theory researchers have tended to overlook high-security risks derived from armed conflict, for example, although high security reflects a key aspect of the institutional environment (Hiatt and Sine, 2014). A high-security risk context, in which organized crime, drug cartels and other non-governmental armed groups criminally operate (e.g. Campbell and Hansen, 2014; Vaccaro and Palazzo, 2015), is understood in this research to be an illegitimate institutional context. In such a context, rules and norms are illegally enforced in civil society and firms by non-governmental armed groups (Parlevliet, 2007; Sutter et al., 2013). In illegitimate institutions, members of civil society, such as employees, have developed norms and behaviors to survive and work in such contexts. We posit that firms operating in illegitimate institutional contexts could overcome illegitimate rules and norms from non-governmental armed groups through informal institutions (North, 1990), which might be a source of competitive advantage (e.g. Doh et al., 2017). Exploring-exploiting informal institutions into management policies and practices is presented as ambidexterity in the following section.
Ambidexterity strategies

201 
MRJIAM

16,2

202

Ambidexterity

Scholars have used the analogy of ambidexterity - the human ability "to use both hands alike" (OED, 2016) - to research firms' ambidexterity. Firms' ambidexterity evolves from conflicting learning activities (March, 1991) interwoven in firms' abilities to exploit, integrate, build and reconfigure internal existing resources, while exploring external resources to address and shape rapidly changing business environments (e.g. Duncan, 1976; Teece, 2016). Firms' exploiting-exploring abilities (O'Reilly and Tushman, 2013; Zimmermann and Birkinshaw, 2016) imply engaging in a duality between:

- experimentation with unknown alternatives to the firm, which might have returns that are "uncertain, distant and often negative" (Hill and Birkinshaw, 2014, p. 2); and

- the exploitation of current capabilities, which means the "refinement and extension of existing competencies, technologies and paradigms," with returns that are "positive, proximate, and predictable" (March, 1991, p. 85).

Traditionally, ambidexterity research focus on firms' duality of learning processes to pursue two conflicting activities at the same time - by developing innovate activities in products, services or new business ventures (e.g. Raisch and Birkinshaw, 2008) - and thus display superior market value and profitability (e.g. D'Souza et al., 2017; Zimmermann and Birkinshaw, 2016). Additionally, ambidexterity research has been conducted at an employee-level of analysis, in relation to resource allocation and the exploration of new business units (March, 1991). For example, Rogan and Mors (2014) suggest that, when assessing the trade-off between exploring new businesses and exploiting existing business, a manager's network serves in the acquisition of knowledge. Mom et al. (2007) performed a quantitative study of electronic firms to discuss how the managers' exploration activities are influenced by bottom-up and horizontal knowledge. This means that front-line managers' knowledge about new technologies or changing market conditions is directly influenced by their subordinates (Mom et al., 2007).

Research on ambidexterity and HRM has been suggested as a strategy to design and implement policies and practices such as flexible time, job security or compensation systems to encourage employees' ambidexterity (Patel et al., 2013; Zimmermann and Birkinshaw, 2016). However, limited research captures variety among employees' ambidexterity ability, even within the same organization, and does not answer why some managers are more ambidextrous than others (e.g. Mom et al., 2015). In this study, we focus on front-line managers and their subordinates contexts, externally to the firms, that might promote bottom-up ambidextrous HRM policies and practices according to the external context.

We position our research on contextual ambidexterity, which is "the behavioral capacity to simultaneously demonstrate alignment and adaptability across an entire business unit" (Havermans et al., 2015, p. 180). Alignment refers to the coherence and balance of exploration-exploitation capabilities, among each individual involved a firm's business activities (Gibson and Birkinshaw, 2004; D'Souza et al., 2017; Zimmermann and Birkinshaw, 2016). Adaptability refers to the capacity to reconfigure activities in a business unit quickly, to meet changing demands in the environment (Gibson and Birkinshaw, 2004, p. 209).

There is a limited amount of research that discusses alignment and balancing of HRM according to changing environment (Raisch and Birkinshaw, 2008; Hill and Birkinshaw, 2014), particularly in an armed conflict context (e.g. Dau et al., 2018). For example, ambidexterity literature at the micro-level of analysis, in relation to employees' abilities to meet organizational goals, tends to overlook employees' abilities to cope with dysfunctional formal institutions (e.g. Rahman and Vuković, 2018; Vaccaro and Palazzo, 2015). In such 
institutional contexts, scholars typically rely on a cultural-cognitive approach (Scott, 2014) to discuss workplace relationships; to propose, for example, a humanistic leadership style (Davila and Elvira, 2012). A humanistic leadership style might imply that a front-line strategies manager is seen as an agent who assigns resources to his/her subordinates - through, for example, corporate social responsibility (CSR) and/or HRM policies (e.g. Davila and Elvira, 2015; Purcell and Hutchinson, 2007). Resources are typically assigned in emerging markets according to employees' circumstances (e.g. d'Iribarne, 2002; Xing et al., 2016). Employees' circumstances in emerging markets are discussed in relation to a limited access to basic human rights, such as education, health and physical security, causing firms to develop mini-welfare states (Marquis and Raynard, 2015) through, for example, CSR investments (e.g. Davila and Elvira, 2015).

Scholars in emerging markets characterized by illegitimate institutions have suggested that employees rely on managers for support in the event of an illegitimate attack (e.g. Andonova et al., 2009). Thus, at the employee level, front-line managers might develop exploitative activities based on their present knowledge and skills, to make short-term improvements (Caniëls and Veld, 2016, p. 3; Gibson and Birkinshaw, 2004; Kang and Snell, 2009) according to employees' circumstances. We propose that ambidexterity (March, 1991) is a key element; it enables front-line managers and their subordinates to design and implement ambidextrous organizational strategies and HRM policies and practices. The following section presents the methods developed in this study.

\section{Methods}

Empirical material was collected over four years (2014-2018) based on archival data, in-depth interviews and conversations with 65 employees in Colombia and Mexico. The main objectives of our semi-structured interviews in, 2014 were to learn strategic, organizational and HRM policies and practices to address the impacts on firms of an illegitimate institutional context and to investigate the perspectives of front-line managers and senior managers at firms visited. Because during the first round of semistructured interviews in 2014, our informants were uncomfortable talking about the violence and crime derived, for example, from narcoterrorism, we implemented two strategies:

(1) Desk research was conducted based on newspapers and publicly available documents on crime and violence to identify illegitimate activities and attacks on firms and civil society.

(2) Based on the outcomes of our initial semi-structured interviews and the desk research, we redesigned our semi-structured interview protocol to reframe our instrument; thus, we developed informal conversations with our informants to continue the fieldwork from 2015 to 2018.

Our conversations involved accounts and interpretations of work contexts, daily routines and outside work contexts to investigate the perspectives of front-line managers and their subordinates on the day-to-day practices implemented to develop their work. We signed confidentiality agreements with the firms and informants that specified that the research outcomes would be used for academic purposes only and that we would not publish any data that could reveal a firm or employee's identity. In this research, we do not provide a table presenting the firms' profiles. The semistructured interviews and conversations with 65 employees occurred between August 2014 and January 2018 at 13 local and foreign firms located in Medellin and Monterrey 
MRJIAM

16,2

204

and lasted an average of 80 minutes. All of the semi-structured interviews and conversations were transcribed.

To ensure the quality of the empirical material (Welch and Piekkari, 2017), we implemented two strategies:

(1) the empirical material was organized with Nvivo11 (qualitative software); and

(2) a detachment procedure (Campbell, 2001) was used to create distance from the key informants and individuals' life experiences and feelings (Davies, 2010) to avoid magnifying their accounts (Gioia et al., 2013).

This procedure involved a thematic analysis to triangulate our empirical materials in NVivo11. Our thematic analysis was conducted by coding our empirical material in accordance with what the texts in our transcripts evoked (Gioia et al., 2013) in relation to the exploration and exploitation strategies of employees and firms to cope with impacts in an illegitimate institutional context. The coding yielded an initial scheme with 25 codes, which were redefined to compare topics across data sources. The data had seven main secondorder themes associated with four aggregate dimensions:

(1) illegitimate institutional context;

(2) organizational explorative-exploitative strategies;

(3) HRM exploitative-explorative strategies; and

(4) employees' exploitative-explorative strategies.

We also identified salient impacts of illegitimate institutional contexts on firms and employees. Next, we present the context of our research and the findings of our thematic analysis.

\section{Research context}

Colombia is home to the world's longest armed conflicts, lasting six decades and resulting in more than 220,000 deaths (Caro, 2016). In 2016, President Santos signed a peace agreement with the FARC (Fuerzas Armadas Revolucionarias de Colombia [Revolutionary Armed Forces of Colombia]). However, the post-conflict stage has been threatened because negotiations between the Colombian government and the rebel army Force National Liberation Army (ELN) were suspended by President Santos on January 29, 2018, after ELN bomb attacks on three police stations nationwide on January 28, 2018. Former Mexican President Mexico Felipe Calderon (2006-2012) implemented a “war on drugs" policy in 2006, resulting in more than 164,000 violent deaths related to organized crime and violence (Breslow, 2015). In 2014, Mexican President Peña Nieto (2012-2018) was portrayed as "saving Mexico", suggesting that Peña Nieto's reforms turned violence and crime around (Crowley and Mascareñas, 2014). However, with 23,101 murders as of December 2017, a record number of murders in modern Mexican history (Reuters in Mexico City, 2017), Mexico's drug war has become the second-most lethal conflict in the world after Syria's conflict (IISS, 2017).

Despite high security risks and other institutional constraints, Colombia's exports as of January, 2017 were 39.9 per cent higher than in January, 2016 (Departamento Administrativo Nacional de Estadística [DANE], 2017). Foreign direct investment (FDI) to Colombia is projected to increase to 3.7 per cent of the gross domestic product (GDP) in 2018 (Corficolombiana, 2018). Mexico attracted a historic record of US $\$ 21,754.9 \mathrm{mn}$ in FDI (January to September 2017) (Secretaría de Economía, 2017). Thus, the armed conflicts in Colombia and Mexico appear to have minor impacts on FDI. The following section presents 
the exploitation and exploration strategies that employees and firms have implemented to be competitive in such an institutional context.

\section{Findings}

Our findings are based on the triangulation of our empirical material developed in our thematic analysis.

\section{Illegitimate institutional context}

This section presents the salient impacts of illegitimate institutional contexts on firms and employees in our research context. According to newspapers and governmental reports, we found direct and indirect impacts of non-governmental armed groups' enforcement on firms. Direct impacts include destruction of firms' infrastructure, facility intrusions, third-party offenses or threats to employees, transport and supply chain attacks, virtual extortion and kidnapping and/or murder of employees (e.g. INEGI, 2016). Indirect consequences include the loss of customers, production interruptions and supply chain disruptions through social unrest, blockades and protests (e.g. Álvarez and Rettberg, 2008; Durbin, 2013; Rettberg, 2003). These impacts have fueled a security and surveillance industry in Colombia of US $\$ 2$ bn per year (export.gov, 2017a) and in Mexico of US\$18.70bn (export.gov, 2017b).

Non-governmental armed groups operate with a sophisticated network and technology to enforce illegal payments, referred to by our informants in Colombia and Mexico as "virtual" extortion. Non-governmental armed groups use unknown procedures within their networks to access personal information about our informants, such as family members' names and activities and credit card numbers, to target potential victims. An informant working in Monterrey's service industry explained that since 2015, there has been a tendency for guests to check into hotels with no suitcases and to have all their meals served there so that they never leave the hotel, which is referred to by our informants as virtual extortion.

Fear was a particularly inductive code repeatedly found in our transcripts. Lorenc et al. (2012) offered a theoretical framework in which they emphasized that fear of crime could have a substantial impact on employees' well-being. For example:

I have noticed that some of our employees continue to be worried from when they leave their homes until they get to work. They [employees] are praying that nothing will happen [...] because there are risks [. . . ] on the public buses, driving their own cars, in taxis, etc. [. . .] well, yes, it is worrying. (Front-line-manager at a local service firm, Mexico)

Our thematic analysis indicates that tension and stress resulting from fear seem to increase concerns regarding being subjected to express kidnapping, explained by our informants as kidnappers taking the victim to a cash point and then releasing him or her, as well as extortion and assaults on the street. For example, extortion integrating advanced technologies, such as use social media (Facebook, WhatsApp, etc.), into their traditional illegal enforcements. These accounts are specific examples of the first-order codes regarding the daily struggles and concerns that emerged from our analysis. A subordinate at a firm in Colombia explained some of the consequences for a firm's operations:

The context [violence and crime] affects us because in some areas, we have had to restrict [our present] coverage of the [dangerous] area. It is very common in the lower stratum [neighborhoods] that there are several types of problems, for example, invisible borders, wars between combos [criminal gangs], restrictions on accessing the area. Then, [based on] prior knowledge of the areas [criminality and violence history], we are [able] to take the necessary [precaution] decisions. Enter or not. (Front-line-manager at a local financial service firm, Colombia)

\section{Ambidexterity strategies}

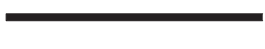


MRJIAM

16,2
The following section presents salient ambidexterity strategies developed at the firms visited.

\section{Organizational exploitation-exploration strategies}

The illegitimate institutional context where the studied firms operate seemed to be taken for granted by our informants. Over the years, the managers implemented strategies to respond to such contexts. For example, all of the studied firms had explicit written security and prevention procedures in relation to armed assaults and extortion calls at work as well as robbery, kidnapping and threats when employees leave the firm's premises. According to our conversations, as the crime and violent attacks increased, more investment firms committed to buying surveillance equipment with a higher level of technology, as in the following example:

From, 2016, the managing team decided to install a surveillance security system for all access to the organization, such as video cameras, bells, panic buttons, etc. Employees with customers were notified that all doors would remain closed from 23:00 pm to 06:00 am. (Manager at a local service firm, Mexico)

We classified these written procedures and hardware installations as exploitative strategies because they are standard practices observed in illegitimate institutional contexts. However, our informants described illegitimate institutional contexts as uncertain and explained that sometimes the organizational policy or protocols do not correspond to the actions actually occurring in such contexts. A front-line manager explained this argument as follows:

The company has security protocols. However, look, what occurs is that one thing is what the protocol states, and another is what would be possible to do. For example, the protocol states that we should make an emergency call in case of a threat or attack. However, when you are in a security risk area, it is completely different than we would expect or as the protocol states [...] there is no signal there - in security risk areas [referring to the signal/satellite connection for communication with the cell phone $][\ldots$... The protocol cannot predict what is going to happen. The protocol would be much more useful if those who followed it did so while in the area. (Blue-collar employee at a local service firm in Colombia)

Other firms have developed a more sophisticated approach, which we classify as an explorative practice. For example, one firm in Colombia has developed security protocols and identification and protection mechanisms to enter conflict zones. The manager explained:

It is important to visibly display the firm's name on uniforms or on the transport fleet to demonstrate that the firm is backing up our employees when they travel to security risk areas. The company is well known [in Colombia][...] our employees always wear our firms' vests, whoever goes. The firms' transportation fleet is always identified with the firm's logo; our drivers transport our employees to unsafe areas and wait for them. (Manager at a local service firm in Colombia)

The exploration of a "new" organizational unit to respond to the direct and indirect effects of security risks on firms seems to have resulted in explorative adjustments to firm budgets. Exploration means to provide employees working on projects located in armed-conflict zones with the ability to negotiate their rescue in case of an attack:

Usually, my immediate manager has decision-making power. For example, once we were on a project in the guerrilla zone; I called her, and she told me, "Get out of there, and then we will see what we do [...] Look for a way to escape [...]" [...] generally when one gets into these areas [guerrilla zones], we also get cash as we need to negotiate with someone to take us [from a 
guerrilla zone] by boat, mule or helicopter, whatever; the important thing is to have some money to negotiate with. This money is given by the corporation, a percentage of the value of the project defined according to the risk of the area. Thus, in this way, we could plan our evacuation. (Bluecollar employee at a local service firm in Colombia)

The thematic analysis of our empirical material allowed us to identify emerging common patterns in relation to information sharing at firms visited. The top management level seemed to be cautious when disseminating sensitive security risk information to employees. A subordinate elaborated on this concept:

[...] We always share information about the description of the area and the characterization of the people. The idea is to develop a precedent, which means considering the history of a [given] zone [e.g., security risk, conditions, people, informants]; at communal meetings, [we can meet] key people, whom we call popular legitimators, meaning loyal defenders of the civil society [. . . . (Bluecollar employee at a local service firm in Colombia)

However, it seems that front-line and HR managers design and disseminate general "common knowledge" about security prevention measures to employees. For example, in our visits to employee common areas, such as cafeterias and locker rooms, we observed posters and TV screens presenting messages about preventative security measures (observations). These security measures appeared to have a positive effect, according to our findings:

$[\ldots$. . the environment [in the organization] has improved [. . .] we have seen it as [our employees] taking more precautions. We designed a few posters [to promote prevention measures] stating, be careful, do not drive alone from home to work, if you do not need to be on the streets at night, please avoid it, etc. [. . .] we have more communication with our employees. (Manager at a local service firm in Mexico)

The firms researched in Colombia and Mexico implemented different strategies to meet international regulations and norms. Firms have established "new" organizational units to comply with C-TPAT (CUSTOM-Trade Partnership against Terrorism) certification (C-TPAT, 2016). The C-TPAT is a certification developed by the US Customs and Border Protection to protect the US border from terrorism (field notes). This organizational strategy seems to be supported by HRM exploitation and exploration policies and practices, which are presented in the following section.

\section{HRM exploitation-exploration strategies}

Organizational exploitation strategies in our study are integrated as a component of HRM policies and practices. Measures such as private transportation for employees to workplaces, flexible timetables, flexible working rules (e.g. work from home), global positioning systems (GPS) on company cars, life insurance and emergency mobile phones are expected by local employees and directors as part of the compensation package in Colombia and Mexico, according to our conversations with HR managers.

In both countries, we found that firms have redesigned their recruitment and selection processes by implementing strict parameters for candidates' first screenings, such as prohibiting employees from having tattoos or relatives in prison because, according to our transcripts, these characteristics are perceived as gang links. In relation to training and development, we noted that firms in both countries have established post-trauma sessions and security prevention programs, not only for employees but also for their families. We also found that only two firms (one Colombian and one Mexican) developed tailored security manuals for their managers traveling to Latin America. One HR manager explained.

For a period of time, all employees received prevention security risk training from the local government Anti Kidnap and Extortion Unit. We did it as our slogan says: safety is everyone's
Ambidexterity
strategies

207 
MRJIAM

16,2

[responsibility], which means that safety is not only a responsibility for the Department of Security. We must be careful, and we need to protect ourselves and be alert with the help of everyone in the organization. (Manager at a local service firm in Mexico)

Our informants also explained that certain establishments have implemented new training programs for receptionists to fight "virtual kidnapping":

If a guest during the check-in process never leaves his/her mobile phone and appears tense [. . . ] do not say a word but show the guest the following flyer, which states, Are you the subject of extortion through calls on your mobile phone from someone who says that you are being watched and that they have kidnapped a relative and thus you need to pay for their rescue? If the guest says yes, then we instruct the receptionist to follow the high-security protocols. (General manager at a local service firm in Mexico)

We classify these initiatives as explorative HRM-related policies and practices. Our empirical material suggests that HRM managers in Colombia and Mexico are challenged by their firms to support the exploitative-explorative HRM policies and practices mentioned above because Europe-based firms do not provide such measures in their own countries. An MNE subsidiary visiting in Colombia appeared to face constraints when implementing HRM explorative practices in relation to:

- maintaining low budgets; and

- investing in benefits and services in an attempt to buffer/diminish the impacts of organized crime and violence.

Our analysis also suggests that individuals at MNE headquarters - where subsidiary budgets are typically approved - have difficulty understanding the effects of security risks on local employees. A Colombian front-line manager working for a Swiss-based firm commented on this topic:

No, they [manager directors] do not know about any of this. Perhaps it may be our own mistake because we [front-line managers] do not communicate [violence and crime incidents] to senior managers. Perhaps the HR department is not aware because we [front-line managers] keep all this information [violence and crime to employees] to ourselves. (Front-line managers at a manufacturing firm, Colombia)

Our field notes on the different semi-structured interviews and conversations suggested that expatriates in Colombia and Mexico seem to develop a misleading understanding of the local illegitimate institutional context. A Colombian employee noted the concern:

[... ] it is because obviously they [expatriates] live in "El Poblado" [an upper-class neighborhood in Medellin][.... . (Front-line manager at a manufacturing firm, Colombia)

We concur with the above observations on the different perceptions and understandings of the local context between expatriates and local employees. Our field study revealed that expatriates who live and work in more privileged areas in Colombia and Mexico seem to be less likely to face the challenges of organized crime and violence, such as not taking public transport or traveling to low-stratum neighborhoods. The presented HRM exploitativeexplorative strategies seem to be executed at the discretion of front-line managers in our sample. These findings are presented below.

\section{Employees' exploitation-exploration practices}

Our conversations with front-line managers suggest that they are embedded in the local illegitimate institutional context. A front-line manager elaborated: 
[... ] as someone said, "We go to some areas where not even God arrives" [...] we go to neighborhoods that are not even on maps. That is where I get scared, because I think, My God, what about if I get stuck here; nobody will find me. (Blue-collar employee at a local service firm, Colombia)

The above quotation illustrates the complexity of the illegitimate institutional context of our research. Our empirical material reveals that local (Colombian and Mexican) employees consider insecurity and risk to be given factors that cannot be changed. Local employees can "deal" with danger and risk, which might be a challenge for expatriates working in Colombia and Mexico. One front-line manager explained:

When we perform an audit [that an expatriate will join], we try to develop it in protected sites. We are not going to put expatriates at a risk where we [local employees] need to go [. . . If I suggest it [a dangerous area], my colleagues say, "How on earth did it occur to you to take Dr. [expatriate] to Robledo [considered by the employees to be a risk area] [... . it is horrible; it is dangerous" [... .] and then, they [expatriates] leave [Colombia] with the feeling that this country is $\mathrm{OK}$, and we are not doing too badly [...]. (Front-line manager in a manufacturing firm, Colombia)

The front-line managers in our study have developed knowledge to execute their explorative ability to make discretionary decisions to protect employees. For example, front-line managers drive their subordinates directly to their homes after dark in the firms' vehicles, or front-line managers pay for a "secure taxi" (a registered taxi firm) or an Uber. See, for example, the following quotation:

We [front-line managers] collect different experiences and particular [struggles] from our employees, who confront specific particularities in their neighborhoods, which are very different among our employees. One collects everything from our employees who have direct contact with security risk issues. (Front-line manager at a local service firm, Colombia)

Our informants argued that violence and crime are "common" in Colombia and Mexico, where an "insecure culture" appears to be embedded in the illegitimate institutional context. According to our empirical analysis, front-line managers do not seem to consider sharing violence and crime-related issues to be relevant. It also seems that front-line managers in manufacturing firms are more concerned with accomplishing work than with security risk issues external to the firm, as a subordinate in Mexico explained:

In fact, it is not the case [...] I say again [...] [the manager] does not speak about insecurity [violence and crime] issues here at work [...] it is clear that work safety [work-related safety measures] is important in relation to the [firm's external] environment, but [he] does not speak about insecurity. (Blue-collar employee at a manufacturing firm, Mexico)

Our conversations also allowed us to learn the traditional norms and behaviors that Colombian and Mexican employees use to cope in uncertain illegitimate institutional contexts. For example, our conversations with front-line managers and subordinates suggest that they "know" how to cope with their daily struggles in illegitimate institutional contexts while meeting their jobs' demands. Front-line managers seem to use their capabilities to discreetly inform or to avoid informing subordinates of security contingencies and to execute organizational and HRM exploitative-explorative strategies. Table I presents a summary of our research context and the ambidexterity strategies above presented. These strategies are discussed in the following section.

\section{Discussion}

Our research question asked: how do firms integrate informal institutions as part of their strategy to meet market demand while coping with the consequences of illegitimate institutional contexts? First, we observed our informants' disillusionment with 


\begin{tabular}{|c|c|c|c|c|}
\hline $\begin{array}{l}\text { MRJIAM } \\
16,2\end{array}$ & \multicolumn{2}{|c|}{$\begin{array}{l}\text { Illegitimate institutional arrangements } \\
\text { Illegitimate rules and } \\
\text { norms that do not reflect } \\
\text { Characteristics the societal values }\end{array}$} & Exploitation & ity strategies \\
\hline 210 & $\begin{array}{l}\text { Impacts } \\
\text { (Direct) }\end{array}$ & $\begin{array}{l}\text { Illegal payments (cuotas/ } \\
\text { vacunas) a form of } \\
\text { extortion and micro- } \\
\text { extortion } \\
\text { Virtual extortions } \\
\text { Threat, express- } \\
\text { kidnapping and/or } \\
\text { murder of employees } \\
\text { Physical destruction, } \\
\text { attacks and/or intrusion } \\
\text { of the firms' infrastructure }\end{array}$ & $\begin{array}{l}\text { Investment in hardware } \\
\text { surveillance equipment } \\
\text { Written security and } \\
\text { prevention procedures } \\
\text { Reinforce HRM policies and } \\
\text { practices, such as: private } \\
\text { transportation, flexible } \\
\text { timetable, life insurance, home } \\
\text { office, etc. }\end{array}$ & $\begin{array}{l}\text { Security protocols to enter } \\
\text { conflict zones } \\
\text { Firm's transportation fleet and } \\
\text { employees' uniforms identified } \\
\text { with the firm's logo } \\
\text { Map invisible borders, (e.g., } \\
\text { wars between gangs) to } \\
\text { restrict firms coverage in such } \\
\text { areas } \\
\text { Redesign recruitment, } \\
\text { selection and training policies } \\
\text { and practices } \\
\text { Adjustment to budgets } \\
\text { according to security-risk } \\
\text { context } \\
\text { "New" organizational units to } \\
\text { comply with C-TPAT }\end{array}$ \\
\hline $\begin{array}{l}\text { Table I. } \\
\text { Ambidexterity } \\
\text { strategies in } \\
\text { illegitimate } \\
\text { institutional contexts }\end{array}$ & $\begin{array}{l}\text { Impacts } \\
\text { (Indirect) }\end{array}$ & $\begin{array}{l}\text { Loss of customers, } \\
\text { production } \\
\text { Interruptions and supply } \\
\text { chain disruptions through } \\
\text { social unrest, blockades } \\
\text { and protests } \\
\text { Employees' fear, tension } \\
\text { and stress }\end{array}$ & $\begin{array}{l}\text { Caution in relation to } \\
\text { information sharing by front- } \\
\text { line manager } \\
\text { Information sharing among } \\
\text { employees (e.g., norms and } \\
\text { behaviors) } \\
\text { Posters and TV screens on } \\
\text { preventive security measures. } \\
\text { Being alert - employees' } \\
\text { embedded behavior }\end{array}$ & $\begin{array}{l}\text { Engagements with popular } \\
\text { legitimator } \\
\text { Front-line managers' ability to } \\
\text { make discretionary decisions } \\
\text { to protect employees } \\
\text { Collection security risk issues } \\
\text { bottom-up (from subordinates) }\end{array}$ \\
\hline
\end{tabular}

dysfunctional formal institutions (North, 1990) and their impacts on employees and firms. The illegitimate institutional context both directly and indirectly impacts on the firms visited in Colombia and Mexico, forcing local employees to exploit-explore informal institutions to meet firms' demands and cope with the direct and indirect impacts of illegitimate threats and attacks. Our findings show how informal institutions (North, 1990) such as the employees' practices and behaviors that enable them to survive in illegitimate institutional contexts - feed normative pillars at organizational levels.

We posit that, at the macro-level, firms exploit traditional investments to provide a miniwelfare state through CSR initiatives (Marquis and Raynard, 2015) and HRM policies and practices. These practices also provide traditional compensation systems with benefits that integrate employees' families, and security systems. However, in an illegitimate institutional context, practitioners would be well-advised to invest in pragmatic and efficient explorative practices, with security and surveillance systems to be proposed bottom-up (i.e. by bluecollar employees). In an illegitimate institutional context, we posit that explorative managerial policies and practices evolve from the formalization of employees' norms and behaviors, thus establishing them as the normative policies and practices at firms.

We extended ambidexterity research at the micro-level of analysis (e.g. Rogan and Mors, 2014) in illegitimate institutional contexts. The rules and norms of such contexts do not 
reflect societal values and basic principles of human rights, such as liberty and trust. The balance of exploration-exploitation in response to illegitimate demands appears to be critical in the context of our research. For example, according to the findings presented, nongovernmental armed groups in Colombia and Mexico appear to have developed sophisticated weaponry by integrating advanced technologies, such as use social media (Facebook, WhatsApp, etc.), into their traditional illegal enforcements, such as violent attacks and intimidations. These illegal enforcements regarding employees leads to tension and stress that, according to our informants, are manifestations of fear - regarding, for strategies example, traveling to and from work. Our informants expressed concerns about being subject to express or virtual kidnapping, extortion and assaults on the street. Thus, Colombians and Mexicans appear to support each other by sharing their cultural-cognitive (Scott, 2014) legacy of norms and behaviors, developed in the illegitimate institutional contexts: in Colombia, six decades of armed conflict; and in Mexico, as the government declared war against narcoterrorism in 2006. We posit that the capacity of employees and firms to recover from armed conflict and narcoterrorism involves a reliance on informal institutions, in which employees use their networks to exploit-explore strategies to protect each other. It seems that being alert is akin to an "innate" embedded behavior in our informants. For example, local employees' behaviors - such as sharing rides in a "secure" taxi or an Uber, or always being alert - appear to encourage normative codes of conduct at a firm level (Scott, 2014). Given the taken-for-granted context in our study, from which a common pattern emerged in our conversations that "nothing can be done," we interpret the "be alert" strategy (e.g. TV, posters) as a reminder, to make explicit to employees the illegitimate institutional context in which they live and work.

Our study also implies the importance of recognizing bottom-up input (blue-collar employees' practices and behaviors) for front-line and HR managers' exploration (i.e. experimentation with new policies and practices). These findings lead us to our first proposition:

P1. When employees rely on informal rather than formal institutions in an illegitimate institutional context, they are likely to exploit and explore strategies within their networks to cope with the consequences of the illegitimate institutional context. Firms are likely to exploit traditional security measures and to integrate employees' explorative strategies into the firm's policies and practices.

At the micro-level, the conceptualization in management studies, such as humanistic leadership (Davila and Elvira, 2012) is analyzed in our research through an ambidexterity theoretical framework. Front-line managers appear to be an important central point for collecting bottom-up knowledge about employees' informal institutions (norms and behaviors), which are then explored and potentially implemented by firms into organizations and HRM as normative policies and practices. These findings offer a different approach to humanistic leadership (Davila and Elvira, 2012), using an ambidexterity lens to observe a symbiotic relationship between front-line managers and their subordinates (Purcell and Hutchinson, 2007). Thus, front-line and HR managers can send signals through managerial policies and practices to indicate that they care about employees and their families. Our findings propose to go beyond the traditional humanistic leadership approaches proposed in Latin America (Davila and Elvira, 2012). For example, we deduce from our findings that such symbiotic relationships in environments characterized by highsecurity risk are not limited to understanding subordinates' lack of access to basic infrastructure and providing access to basic needs through HRM and CSR systems. Instead, front-line managers advocate subordinates' input (practices and behaviors developed based 
MRJIAM

16,2 on the illegitimate institutional legacy) to top management teams when designing and implementing exploration-exploitation policies and practices.

Our findings also suggest emerging internal and external powers at firms (i.e. subordinates and popular legitimators, respectively), referred as salient stakeholders that emerge during crises (Davila and Molina, 2017). These findings suggest that it is not sufficient for front-line managers in illegitimate institutional contexts to be competent at their jobs. Front-line managers must also be savvy in the local context to strategically function as intermediaries, allowing them to propose ambidextrous strategies to senior managers and entire organizational units. In short, front-line managers appear to be key players in firms as a recombination of dispersed employees' ambidextrous norms and behaviors. Thus, we posit that front-line managers' ambidexterity, with respect to the dissemination and implementation of organizational and HRM policies and practices, could represent an organizational advantage when they recognize and value knowledge from informal institutions (e.g. Doh et al., 2017).

During the course of our research, some informants were uncomfortable openly discussing security risk issues, which caused us to modify our research strategy, as presented in our Methods section. We posit that individuals deploy avoidance (e.g. Oliver, 1991) to verbalize and reflect the impacts of narcoterrorism and armed conflict on civil society and firms. We interpret this behavior as a lack of trust in formal institutions and as a mechanism to forget and negate this reality - an attempt to demonstrate that "everything is fine". These norms and behaviors are not explicitly discussed in illegitimate institutional contexts because, according to our informants, security risk issues are "normal" in such contexts; for example, the avoidance of certain scenarios such as expatriates supervising blue-collar employees at "invisible borders". This fact seems to have implications for approving budgets for explorative HRM strategies to protect employees in Colombia and Mexico. These findings suggest that explorative policies and practices based on trust, openness, participation, and honesty, among other values - which contradict the values imposed by non-governmental armed groups - should be emphasized in management practices. Trust and participation, among other values, could serve as a strategy to "fight" the lack of trust in formal institutions and to support members of society against the proliferation of organized crime and violence.

Our findings advance our understanding of contextual ambidexterity (e.g. Colville et al., 2013; Havermans et al., 2015) as something that is developed by firms in security risk contexts by aligning and integrating all organizational units (alignment), with security policies that represent the changing circumstances of the workplace (adaptability). This requirement leads us to present our second proposition:

P2. When employees face security risks in illegitimate institutional contexts, they are more likely to seek support from their front-line managers than from formal institutions. The front-line manager is likely to be an intermediary between subordinates and senior managers in the formalization of employees' informal norms and behaviors into policies and practices.

Mexico's murder rate in 2017 and the ELN's 2018 attacks in Colombia suggest that the coercive (Scott, 2014) measures implemented in both countries have accomplished little in the fight against narcoterrorism and non-governmental armed groups. Thus, HR departments at the visited firms had designed and implemented a strict set of parameters for recruitment, selection and training, among other practices. For example, screening procedures are implemented before recruitment, in terms of employee profile, to avoid employing a member of a non-governmental armed group; these procedures appeared to be standard in the context of our research. External influences, such as the US's C-TPAT 
certification, appear to be a normative pillar with an obligatory dimension (Scott, 2014) for firms in Colombia and Mexico that aim to continue exporting to the US market. This fact leads us to the following proposition:

P3. The increasing direct and indirect impacts on firms of illegitimate rules and norms enforced by non-governmental armed groups leads to an increased number of security homogeneity measures at firms.

Ambidexterity strategies

\section{Limitations and future research}

Our sample of a limited number of local firms and MNE subsidiaries in Medellin and Monterrey presents challenges regarding the findings. However, we advanced our knowledge and understanding of institutional theory by recognizing illegitimate institutions as components of the institutional environment found in our research context, which seems to have ramifications for more advanced institutional contexts. For example, the recent terrorist attacks in Europe, Canada and the USA, corrupt governments (Transparency International, 2018) and armed conflicts around the world (IISS, 2017) provide evidence of the operation of illegitimate institutions. Thus, our results provide strategies that can inspire future research in more advanced institutional contexts. We propose going beyond traditional institutional assumptions to study MNEs in emerging and developed markets.

We invite scholars to revise our views regarding the use of traditional institutional theory and research in the study of organizational and HRM strategies. Scholars seem to ignore the interface between ambidexterity and institutional theory and research. Our study presents rich on-the-ground empirical evidence of the strategies adopted in response to illegitimate institutional contexts by incorporating the ambidexterity approach. All of the visited firms juggle competing, complex, and occasionally contradictory agendas (e.g. how to address international competition as well as local violence and crime). Although the illegitimate context could be viewed as an extreme example, our observations through the lens of ambidexterity enable us to explain how the visited firms can remain internationally competitive.

Future research could test our propositions by analyzing sudden changes in formal institutions, such as US President Trump's "America First” foreign policy, which aims at "renegotiating NAFTA and bring[ing] jobs back to America's shores" (White House, 2017). Applying the ambidexterity approach to a changing institutional context could facilitate organizational, HRM and employees' explorative and exploitative strategies to strategically respond to an emerging, changing present (e.g. Colville et al., 2013).

\section{Conclusions}

The illegitimate institutional context in our study is characterized by the uncertainty imposed by non-governmental armed groups on governments, firms and civil society, through criminal attacks and threat enforcement. We posit that in such a context, with a perceived inability to predict the organization's external impacts, firms can learn from the informal institutions - socially constructed and shared rules and constraints - developed bottom-up by employees and front-line managers to survive.

Front-line manager ambidexterity appears to provide a powerful ability to cope with the institutional complexities found in environments characterized by high-security risks. Local employees might be instrumental in providing granular input to design ambidextrous strategies for local subsidiaries, thus obtaining approval from 
MRJIAM

16,2

headquarters for investment in security measures. This work represents an important contribution because it contextualizes aspects and issues that are external and unfamiliar to international scholars and practitioners and yet are of global concern due to terrorism and armed conflict.

\section{References}

Alcadipani, R. and Rosa, A.R. (2011), "From grobal management to glocal management: Latin American perspectives as a counter-dominant management epistemology", Canadian Journal of Administrative Sciences/Revue Canadienne Des Sciences De L'administration, Vol. 28 No. 4, pp. 453-466.

Álvarez, S. and Rettberg, A. (2008), "Cuantificando los efectos económicos del conflicto: una exploración de los costos y los estudios sobre los costos del conflicto armado colombiano [quantifying the economic effects of the conflict: an exploration of costs and cost studies of the colombian armed conflicto]", Colombia Internacional, Vol. January-June No. 67, pp. 14-37.

Andonova, V., Gutierrez, R. and Avella, L.F. (2009), "Three cases from Colombia”, in Davila, A. and Elvira, M.M. (Eds), Best Human Resource Management Practices in Latin America, Routledge, London, pp. 25-26.

Bader, B., Berg, N. and Holtbrügge, D. (2015), "Expatriate performance in terrorism-endangered countries: the role of family and organizational support", International Business Review, Vol. 24 No. 5, pp. 849-860.

Breslow, J.M. (2015), “The staggering death toll of Mexico's drug war”, Frontline, available at: www.pbs. $\mathrm{org} / \mathrm{wgbh} /$ frontline/article/the-staggering-death-toll-of-mexicos-drug-war/ (accessed 17 March, 2016).

C-TPAT (2016), "Customs-trade partnership against terrorism", available at: www.cbp.gov/BORDERSECURITY/PORTS-ENTRY/CARGO-SECURITY/C-TPAT-CUSTOMS-TRADE-PARTNERSHIPAGAINST-TERRORISM (accessed 17 March 2016).

Campbell, J.R. (2001), "Participatory rural appraisal as qualitative research: distinguishing methdology issues from participatory claims", Human Organization, Vol. 60 No. 4, pp. 380-389.

Campbell, H. and Hansen, T. (2014), "Is Narco-Violence in Mexico terrorism?", Bulletin of Latin American Research, Vol. 33 No. 2, pp. 158-173.

Caniëls, M.C.J. and Veld, M. (2016), "Employee ambidexterity, high performance work systems and innovative work behaviour: how much balance do we need?", The International Journal of Human Resource Management, pp. 1-21.

Cantwell, J., Dunning, J.H. and Lundan, S.M. (2010), “An evolutionary approach to understanding international business activity: the co-evolution of MNEs and the institutional environment", Journal of International Business Studies, Vol. 41 No. 4, pp. 567-586.

Caro, C.J.V. (2016), “Colombia armed conflict: arms for peace”, Forbes Opinion, available at: www. forbes.com/sites/realspin/2016/09/19/colombian-armed-conflict-arms-for-peace/\#3209cb0428f0 (accessed 17 March 2016).

Colville, I., Pye, A. and Carter, M. (2013), "Organizing to counter terrorism: sensemaking amidst dynamic complexity", Human Relations, Vol. 66 No. 9, pp. 1201-1223.

Corficolombiana (2018), "Proyecciones económicas", available at: http://bit.ly/2DUfVwx (accessed 2 February 2018).

Crowley, M. and Mascareñas, D. (2014), “The committee to save Mexico”, Time Magazine, Vol. 138 No. 7, pp. 34-38, 24 February.

Davies, J. (2010), "Introduction: Emotions in the field", in Davies, J. and Spencer, D. (Eds), Emotions in the Field: The Psychology and Anthropology of Fieldwork Experience, Stanford University Press, Stanford, CA, pp. 1-31. 
Davila, A. and Elvira, M.M. (2012), "Humanistic leadership: lessons from Latin America", Journal of World Business, Vol. 47 No. 4, pp. 548-554.

Davila, A. and Elvira, M.M. (2015), "Human resource management in a kinship society: the case of Latin America", in Horwitz, F. and Budhwar, P. (Eds), Handbook of Human Resource Management in Emerging Markets, Edward Elgar Publishing, Cheltenham, pp. 372-392.

Davila, A. and Molina, C. (2017), "From silent to salient stakeholders: a study of a coffee cooperative and the dynamic of social relationships", Business and Society, Vol. 56 No. 8, pp. 1195-1224.

Ambidexterity strategies

Dau, L.A., Moore, E.M. and Abrahms, M. (2018), "Global security risks, emerging markets and firm responses: assessing the impact of terrorism", in Castellani, D., Narula, R., Nguyen, Q.T.K., Surdu, I. and Walker, J.T. (Eds), Contemporary Issues in International Business: Institutions, Strategy and Performance, Springer International Publishing, Cham, pp. 79-97.

Departamento Administrativo Nacional de Estadística (DANE) (2017), "Boletín técnico- Exportaciones, 2017”, available at: www.dane.gov.co/index.php/estadisticas-por-tema/comercio-internacional/ exportaciones (accessed 2 February 2018).

d'Iribarne, P. (2002), "Motivating workers in emerging countries: universal tools and local adaptations", Journal of Organizational Behavior, Vol. 23 No. 3, pp. 243-256.

DiMaggio, P.J. and Powell, W.W. (1983), "The iron cage revisited: institutional isomorphism and collective rationality in organizational fields", American Sociological Review, Vol. 48 No. 2, pp. 147-160.

Doh, J., Rodrigues, S., Saka-Helmhout, A. and Makhija, M. (2017), "International business responses to institutional voids", Journal of International Business Studies, Vol. 48 No. 3, pp. 293-307.

Duncan, R.B. (1976), "The ambidextrous organization: designing dual structures for innovation", in Kilmann, R.H., Pondy, L.R. and Slevin, D. (Eds), The Management of Organization Design: Strategies and Implementation, Elsevier Science Publishing, North Holland, New York, NY, Vol. 1, pp. 167-188.

Durbin, K.J. (2013), "International narco-terrorism and non-state actors: the drug cartel global threat", Global Security Studies, Vol. 4 No. 1, pp. 16-30.

D’Souza, D., Sigdyal, P. and Struckell, E. (2017), "Relative ambidexterity: a measure and a versatile framework", Academy of Management Perspectives, Vol. 31 No. 2, pp. 124-136.

export.gov (2017a), "Colombia - safety and security", available at: www.export.gov/article?id= Colombia-Safety-and-Security (accessed 1 February 2018).

export.gov (2017b), "Mexico country commercial guide", available at: www.export.gov/article?id= Mexico-Safety-and-Security (accessed 1 February 2018).

Ganson, B. and Wennmann, A. (2016), Business and Conflict in Fragile States: The Case for Pragmatic Solutions, International Institute for Strategic Studies (IISS), Oxon.

Gibson, C.B. and Birkinshaw, J. (2004), "The antecedents, consequences, and mediating role of organizational ambidexterity", Academy of Management Journal, Vol. 47 No. 2, pp. 209-226.

Gioia, D.A., Corley, K.G. and Hamilton, A.L. (2013), "Seeking qualitative rigor in inductive research", Organizational Research Methods, Vol. 16 No. 1, pp. 15-31.

Havermans, L.A., Den Hartog, D.N., Keegan, A. and Uhl-Bien, M. (2015), "Exploring the role of leadership in enabling contextual ambidexterity", Human Resource Management, Vol. 54 N. S1, pp. 179-200.

Hiatt, S.R. and Sine, W.D. (2014), "Clear and present danger: planning and new venture survival amid political and civil violence", Strategic Management Journal, Vol. 35 No. 5, pp. 773-785.

Hill, S.A. and Birkinshaw, J. (2014), "Ambidexterity and survival in corporate venture units", Journal of Management, Vol. 40 No. 7, pp. 1899-1931. 
MRJIAM 16,2

IISS, The International Institutte for Strategic (2017), Armed Conflict Survey, 2017: The Worldwide Review of Political, Military and Humanitarian Trends in Current Conflicts, Routledge, London.

INEGI (2016), Encuesta Nacional de Victimización y Percepción sobre Seguridad Pública (ENVIPE) (National Survey of Victimization and Perceptions of Public Safety), Instituto Nacional de Estadística y Geografía, Mexico.

Kang, S.A. and Snell, S.A. (2009), "Intellectual Capital architectures and ambidextrous learning: a framework for human resource management", Journal of Management Studies, Vol. 46 No. 1, pp. 65-92.

Lorenc, T., Clayton, S., Neary, D., Whitehead, M., Petticrew, M., Thomson, H., Cummins, S., Sowden, A. and Renton, A. (2012), "Crime, fear of crime, environment, and mental health and wellbeing: mapping review of theories and causal pathways", Health and Place, Vol. 18 No. 4, pp. 757-765.

March, J.G. (1991), "Exploration and exploitation in organizational learning", Organization Science, Vol. 2 No. 1, pp. 71-87.

Marquis, C. and Raynard, M. (2015), "Institutional strategies in emerging markets", Academy of Management Annals, Vol. 9 No. 1, pp. 291-335.

Martínez Rangel, R. and Reyes Garmendia, E. (2012), "El consenso de Washington: la instauración de las políticas neoliberales en América Latina”, Politica y Cultura, Vol. 37, pp. 35-64.

Mom, T.J.M., Fourné, S.P.L. and Jansen, J.P. (2015), "Managers' work experience, ambidexterity, and performance: the contingency role of the work context", Human Resource Management, Vol. 54 No. S1, pp. s133-s153, available at: http://dx.doi.org/10.1002/hrm.21663

Mom, T.J., Van Den Bosch, F.A. and Volberda, H.W. (2007), "Investigating managers' exploration and exploitation activities: the influence of top-down, bottom-up, and horizontal knowledge inflows", Journal of Management Studies, Vol. 44 No. 6, pp. 910-931.

North, D.C. (1990), Institutions, Institutional Change and Economic Performance, Cambridge University Press, Cambridge.

OED (2016), "Ambidextrous, Oxford English dictionary (OED)", available at: www.oed.com/view/ Entry/6128? redirectedFrom=ambidextrous\#eid (accessed 17 March, 2016).

Oliver, C. (1991), "Strategic responses to institutional processes", Academy of Management Review, Vol. 16 No. 1, pp. 145-179.

O'Reilly, C.A. and Tushman, M.L. (2013), "Organizational ambidexterity: past, present, and future”, Academy of Management Perspectives, Vol. 27 No. 4, pp. 324-338.

Parlevliet, J. (2007), "Defining (informal) institutions: informal institutions", in Jüttin, J., Dreschsler, D., Bartsch, S. and de Soysa, I. (Eds), Informal Institutions: Hos Social Norms Help or Hinder Development, OECD Development Center, Paris, pp. 44-48

Patel, P.C., Messersmith, J.G. and Lepak, D.P. (2013), "Walking the tightrope: an assessment of the relationship between high-performance work systems and organizational ambidexterity", Academy of Management Journal, Vol. 56 No. 5, pp. 1420-1442.

Paauwe, J. and Boselie, P. (2003), “Challenging 'strategic HRM' and the relevance of the institutional setting”, Human Resource Management Journal, Vol. 13 No. 3, pp. 56-70.

PlanetRulers (2018), "PlanetRulers - current heads of state and dictators", Current World Dictators, available at: https://planetrulers.com/current-dictators/ (accessed 1 March 2018).

Purcell, J. and Hutchinson, S. (2007), "Front-line managers as agents in the HRM-performance causal chain: theory, analysis and evidence”, Human Resource Management Journal, Vol. 17 No. 1, pp. 3-20.

Raisch, S. and Birkinshaw, J. (2008), "Organizational ambidexterity: antecedents, outcomes, and moderators", Journal of Management, Vol. 34 No. 3, pp. 375-409.

Rahman, E. and Vuković, S. (2018), "Sympathy for the devil: when and how to negotiate with criminal gangs - case of El Salvador", Studies in Conflict and Terrorism, Vol. 49 No. 2, pp. 1-18. 
Rao, H. and Greve, H.R. (2018), "Disasters and community resilience: Spanish flu and the formation of retail cooperatives in Norway", Academy of Management Journal, Vol. 61 No. 1, pp. 5-25.

Ambidexterity strategies

Rettberg, A. (2003), "Administrando la adversidad: respuestas empresariales al conflicto colombiano. [managing adversity: business responses to the Colombian conflict]", Colombia Internacional, Vol. 55, pp. 37-54.

Reuters in Mexico City. (2017), "Murder statistics reveal, 2017 to be the deadliest year in Mexico's history", The Guardian, Mexico City, (23 December), available at: www.theguardian.com/world/2017/dec/23/ new-figures-reveal-2017-to-be-the-deadliest-year-in-mexicos-history (accessed 1 February 2018).

Rogan, M. and Mors, M.L. (2014), "A network perspective on individual-level ambidexterity in organizations", Organization Science, Vol. 25 No. 6, pp. 1860-1877.

Rosen, A., Bender, J. and Macias, A. (2016), "The 50 most violent cities in the world”, Business Insider, Military and Defense, available at: www.businessinsider.com/most-violent-cities-in-the-world2016-1? $\mathrm{r}=\mathrm{US} \& \mathrm{IR}=\mathrm{T} \& \mathrm{IR}=\mathrm{T}$ (accessed 17 March 2017).

Secretaría de Economía (2017), "Inversión extranjera directa en méxico y en el mundo -Carpeta de información estadística, Mexico city”, available at: www.gob.mx/cms/uploads/attachment/file/ 279079/Carpeta_IED.pdf (accessed 2 February 2018).

Scott, W.R. (2014), Institutions and Organizations: Ideas, Interests, and Identities, 4th ed., SAGE, Los Angeles, CA.

Sutter, C.J., Webb, J.W., Kistruck, G.M. and Bailey, A.V.G. (2013), "Entrepreneurs' responses to semiformal illegitimate institutional arrangements", Journal of Business Venturing, Vol. 28 No. 6, pp. 743-758.

Teece, D.J. (2016), "Dynamic capabilities”, in Augier M. and Teece D. (Eds), The Palgrave Encyclopedia of Strategic Management, Palgrave Macmillan, London.

The Economist (2018), "How the west got China wrong", Geopolitics, available at: www-economist-com. esc-web.lib.cbs.dk:8443/news/leaders/21737517-it-bet-china-would-head-towards-democracyand-market-economy-gamble-has-failed-how (accessed 3 March 2018).

Transparency International (2018), "Corruption perception index, 2017", www.transparency.org/news/ feature/corruption_perceptions_index_2017 (accessed 1 March 2018).

Vaccaro, A. and Palazzo, G. (2015), "Values against violence: institutional change in societies dominated by organized crime", Academy of Management Journal, Vol. 58 No. 4, pp. 1075-1101.

Welch, C. and Piekkari, R. (2017), "How should we (not) judge the 'quality' of qualitative research? A reassessment of current evaluative criteria in international business", Journal of World Business, Vol. 52 No. 5, pp. 714-725.

White House (2017), “America first foreign policy”, available at: www.whitehouse.gov/america-firstforeign-policy (accessed 17 March 2016).

Williamson, J. (2008), "A short history of the Washington consensus", Law and Business Review of the Americas, No. 15, pp. 7-24.

Woody, C. (2017), "The 50 most violent cities in the world", Business Insider Nordic, http://nordic. businessinsider.com/most-violent-cities-in-the-world-2017-4?r=US\&IR=T (accessed 27 February 2018).

Xing, Y., Liu, Y., Tarba, S.Y. and Cooper, C.L. (2016), "Intercultural influences on managing African employees of Chinese firms in Africa: Chinese managers' HRM practices", International Business Review, Vol. 25 No. 1, pp. 28-41.

Zimmermann, A. and Birkinshaw, J. (2016), "Reconciling capabilities and ambidexterity theories", in Teece, D.J. and Leih, S. (Eds), Reconciling Capabilities and Ambidexterity Theories: A Multi-Level Perspective, Vol. 1, Oxford University Press, Oxford. 
MRJIAM

16,2

218

\section{Further reading}

FARC-EP (2018), "Fuerzas armadas revolucionarias de Colombia", available at: www.farc-ep.co (accessed 30 January, 2018).

Hernández, G.C., Valencia, J.N. and Giraldo, C.A. (2010), “Gestión humana en la empresa colombiana: sus características, retos y aportes. Una aproximación a un sistema integral [human resource management in colombian businesses: its characteristics, challenges, and contributions: an approach to an integral system]", Cuadernos De Administración, Vol. 23 No. 41, pp. 13-36.

US Trade Representative Mexico (2016), "Mexico, US-Mexico trade facts”, available at: https:/ustr.gov/ countries-regions/americas/mexico (accessed 31 January 2018).

\section{Corresponding author}

Jacobo Ramirez can be contacted at: jara.msc@cbs.dk

For instructions on how to order reprints of this article, please visit our website: 